\title{
PENGARUH CASH HOLDING, PROFITABILITAS, DAN FINANCIAL LEVERAGE TERHADAP INCOME SMOOTHING PADA PERUSAHAAN MANUFAKTUR
}

\author{
IBRAM PINONDANG DALIMUNTHE ${ }^{1}$, WONI PRANANTI \\ Prodi Akuntansi S1, Fakultas Ekonomi, Universitas Pamulang \\ *Email : ibram@unpam.ac.id ${ }^{1}$
}

\begin{abstract}
The objectives of this study are examine whether manufacture companies sector basic industry and chemicals that is listed in Indonesia Exchange over periode 2013-2017 do earning management with income smoothing through manipulating the amount of loan loss provisions along with influenced factors. Dependent variable used in this study is income smoothing, independent variables used in this study is cash holding, profitabilitas (net profit margin), and financial leverage (debt to equity ratio). This research used purposive sampling and kuantitatif, in determining sampel selection. A total of 22 companies sampel from 66 companies population. Eckel's coefficient was used as a tool to indentify income smoothing. Subsequently performed descriptive statistics and logistic regression analysis to test each hypothesis by used eviews 7.0. The results of this study found that cash holding had no effect to income smoothing, profitability proxied by net profit margin and financial leverage proxied by debt to equity ratio had effect to income smoothing. and Simultaneously the cash holding, profitability, financial leverage had significantly effect to income smoothing.
\end{abstract}

Keywords: Income Smoothing, Cash Holding, Profitability, Financial Leverage.

\section{PENDAHULUAN}

Pasar modal di Indonesia saat ini semakin berkembang sehingga membuat persaingan antar perusahaan semakin ketat. Perusahaan akan selalu berusaha meningkatkan nilai perusahaan agar investor semakin tertarik untuk menginvestasikan dananya di perusahaan. Investor yang rasional akan memilih berinvestasi di perusahaan yang memiliki prospek yang bagus di periode mendatang. Oleh sebab itu, para investor menaruh perhatian yang besar mengenai informasi-informasi yang diungkapkan oleh perusahaan. SFAC (Statement of Financial Accounting Concept) No.1 menyebutkan bahwa pada umumnya informasi laba yang diungkapkan perusahaan adalah perhatian utama di dalam menaksir kinerja atau pertanggungjawaban manajemen dan juga membantu pemilik untuk melakukan penaksiran atas kekuatan laba (earning power) perusahaan di periode mendatang.

Investor cenderung hanya memperhatikan angka laba yang disajikan dalam laporan keuangan tanpa mempertimbangkan proses yang dilakukan untuk 
mendapatkan laba tersebut (Algery, 2013). Perhatian Investor tidak berfokus pada informasi prosedur dan metode yang digunakan untuk menghasilkan informasi laba tersebut memotivasi manajemen untuk melakukan tindakan manajemen laba (Harnovisah, dkk, 2015).

Standar Akuntansi Keuangan (SAK), memberikan fleksibilitas bagi manajemen untuk memilih kebijakan akuntansi yang lebih mempresentasikan keadaan perusahaan sesungguhnya. Fleksibiltas itulah yang terkadang dimanfaatkan oleh manajemen untuk melakukan manajemen laba (earnings management). Seperti yang telah dijelaskan oleh PSAK No. 25 bahwa manajemen berhak menggunakan pertimbangannya dalam mengembangkan dan menerapkan suatu kebijakan akuntansi yang relevan dan andal untuk kebutuhan pengambilan keputusan ekonomi.

Terdapat beberapa kasus mengenai skandal laporan keuangan yang ada di Indonesia yaitu skandal manipulasi laporan keuangan, salah satunya yaitu PT KAI ada perbedaan pandangan antara manajemen dan komisaris. Komisaris menolak untuk menyetujui dan menandatangani laporan keuangan yang telah diaudit oleh auditor eksternal, ketika dilakukan audit ulang ternyata pada tahun 2005 PT KAI mencatat keuntungan Rp6,9 miliar yang seharusnya Rp6,3 miliar. Dengan perencanaan bonus yang didasarkan pada data akuntansi mendorong manajemen untuk melakukan manipulasi data akuntansi tersebut untuk menaikkan laba agar setiap pihak meningkatkan bonus tahunan. (bisnis.tempo.co).

Kasus PT Indofarma Tbk bermula dari adanya penelahaan Bapepam mengenai dugaan pelanggaran peraturan perundang-undangan di bidang pasar modal terkait dengan penyajian laporan keuangan yang dilakukan manajemen PT Indofarma Tbk. Bapepam menemukan bukti yaitu nilai barang dalam proses di nilai lebih tinggi dari nilai seharusnya (overstated) dalam penyajian nilai persediaan barang dalam proses pada tahun buku 2001 sebesar Rp28,87 miliar, akibatnya penyajian terlalu tinggi (overstated) persediaan sebesar Rp28,87 miliar, tetapi harga pokok penjualan disajikan terlalu rendah dan laba bersih disajikan terlalu tinggi dengan nilai yang sama. (detik.com)

Income smoothing berkaitan dengan teori agensi (agency theory). Teori agensi merupakan hubungan principal dan agent yang dapat diasumsikan bahwa tiap-tiap individu semata-mata termotivasi oleh kepentingan diri sendiri (Anthony dan Govindarajan, 2005:269). Dalam teori ini, agent adalah manajemen sedangkan principal adalah pihak-pihak yang menyerahkan modalnya untuk dikelola oleh manajemen. Pihak-pihak yang dimaksud yaitu pemengang saham dan kreditur. Dalam teori ini agent tertarik kepada kompensasi keuangan dan kebutuhan psikologinya serta hal lain yang terkait dengan hubungan keagenan sedangkan principal cenderung hanya tertarik pada jumlah pengembalian atas investasi yang dikeluarkan, sehingga hal ini menimbulkan konflik, adanya konflik kepentingan yang terjadi menyebabkan manajemen melakukan tindakan yang tidak semestinya dengan menyajikan informasi yang tidak sebenarnya kepada pemilik yaitu dengan melakukan manajemen laba (Badera dan Dewantari, 2015).

Watts dan Zimmerman (1986) dalam Widyaningdyah (2001:92), secara empiris memberikan gambaran yang berkaitan dengan hubungan antara agen dan prinsipal sering ditentukan oleh angka akuntansi. (Muchammad, 2001:19) Dalam 
hal ini mendorong manajemen (agen) untuk berupaya mengolah angka akuntansi menjadi sedemikian rupa melalui cara yang sistematis dengan memilih kebijakan atau metode tertentu sehingga angka akuntansi (laba) yang dilaporkan dari periode ke periode dapat benar-benar mencapai tujuan akhir yang diharapkan.

Perataan laba dalam laporan keuangan merupakan hal biasa dan dianggap masuk akal. Income smoothing di dorong oleh berbagai faktor yang dibedakan atas faktor konsekuensi ekonomi dari pilihan akuntansi dan faktor laba. Faktor konsekuensi dari pilihan akuntansi merupakan kondisi yang dipengaruhi oleh angka-angka akuntansi sehingga perubahan akuntansi yang mempengaruhi angkaangka akuntansi akan mempengaruhi kondisi tersebut, sedangkan faktor laba adalah pengaruh dari angka-angka laba periodik yang dengan sendirinya juga mendorong perilaku perataan laba. Perataan laba tidak akan terjadi jika laba yang diharapkan tidak terlalu berbeda dengan laba yang sesungguhnya (Algery, 2013).

Menurut Cendy (2013), menyatakan bahwa perhatian investor sering kali hanya terpusat pada informasi laba yang diberikan oleh perusahaan bukan hanya terpusat pada informasi laba yang diberikan oleh perusahaan dan bukan pada prosedur yang digunakan dalam perusahaan untuk menghasilkan informasi laba tersebut, sehingga dapat memberikan kesempatan bagi manajemen untuk melakukan tindakan manipulasi laba dengan salah satu caranya adalah melakukan income smoothing.

Menurut Aji dan Mita (2010), teknik-teknik pengelolaan laba yang oportunistik seringkali menggunakan teknik income smoothing. income smoothing disebabkan adanya motivasi manajemen untuk mengurangi fluktuasi laba yang dilaporkan. Manajemen memilih untuk menjaga nilai laba yang stabil dibandingkan nilai laba yang cenderung bergejolak, Sehingga manajemen akan menaikan laba yang dilaporkan jika jumlah laba yang sebenarnya menurun dari laba tahun sebelumnya. Sebaliknya manajemen akan memilih untuk menurunkan laba yang dilaporkan jika laba yang sebenarnya meningkat dibandingkan dengan laba tahun sebelumnya (Cendy, 2013). Laba yang rata dari tahun ke tahun sangat disukai oleh investor dan kreditur, karena laba yang rata mengindikasikan bahwa perusahaan tersebut kuat dan stabil (Arif, 2014). Penelitian ini menguji tiga variabel yang di duga dapat mempengaruhi terjadinya income smoothing antara lain Cash holding, profitabilitas, financial leverage.

Cash holding didefinisikan menurut Jasen (1986) dalam mambraku (2014) sebagai kas yang dimiliki perusahaan, yang sifatnya jangka pendek. Berdasarkan agency theory, adanya konflik antara manajemen dan pemegang saham menimbulkan keinginan manajemen untuk memegang kas (cash holding) di perusahaan dan menjaga kestabilan kenaikan kas yang ada di perusahaan, karena kenaikan kas yang stabil di perusahaan membuat kinerja manajemen terlihat baik dimata pemegang saham. Kebijakan cash holding yang dikendalikan oleh manajer inilah yang meningkatkan motivasi manajemen untuk mementingkan kepentingan pribadi dengan cara melakukan earning management dalam bentuk income smoothing. Hal ini sejalan dengan penelitian Mohammadi et. Al (2012) yang menyatakan cash holding berhubungan dan berhubungan langsung dengan income smoothing, yang berarti bahwa semakin tinggi kepemilikan kas atau semakin tinggi kas yang ada dalam perusahaan maka semakin tinggi income smoothing. 
Hal ini selaras dengan penelitian yang dilakukan oleh Cendy (2012) yang menyatakan cash holding berpengaruh positf terhadap perataan laba (income smoothing).

Profitabilitas yang diukur dengan net profit margin (NPM) mempunyai pengaruh terhadap perataan laba jika profitabilitas (NPM) tinggi maka perusahaan akan mempunyai nilai tambah bagi investor. Hal ini sama juga ditunjukan terhadap para calon investor potensial, dimana diharapkan mereka akan tertarik membeli saham perusahaan. Dengan demikian, perusahaan akan cenderung melakukan perataan laba agar profitabilitas (net profit margin) selalu baik. Akan tetapi hasil yang beda ditunjukan pada penelitian oleh Sumtaky (2007), profitabilitas (net profit margin) tidak berpengaruh terhadap perataan laba karena kemungkinan perusahaan menggunakan pendanaan hutang yang cukup besar, sehingga struktur modalnya optimal dan menghasilkan laba yang relatif rendah. Margin laba yang rendah menunjukkan tidak ada masalah dalam operasi perusahaan sehingga perusahaan memiliki tingkat pengembalian yang tinggi bagi para pemegang saham.

Perusahaan yang memiliki profitabilitas yang tinggi cenderung untuk melakukan perataan laba karena manajemen mengetahui kemampuan perusahaan untuk mendapatkan laba pada masa yang akan mendatang (Budiasih, 2009), profitabilitas yang stabil akan menguntungkan manajemen, seperti mempertahankan posisi jabatan apabila kinerja diukur dengan tingkat laba yang mampu dihasilkan. Berdasarkan penelitian Cendy (2013) yang menguji profitabilitas terhadap income smoothing memiliki perbedaan pengaruh antara perusahaan manufaktur dan perusahaan jasa, karena laba di perusahaan manufaktur lebih bersifat fluktatif, sedangkan laba di perusahaan jasa bersifat relatif stabil, sehingga kecenderungan untuk melakukan income smoothing lebih besar pada perusahaan manufaktur.

Financial leverage yaitu sebuah rasio untuk mengukur seberapa baik struktur permodalan perusahaan. Rasio ini berhubungan dengan hutang yang dimiliki perusahaan terhadap pihak kreditur. Kreditur dalam memberikan pinjaman kepada perusahaan mengacu pada laba yang diperoleh perusahaan, financial leverage (debt to equity ratio) menggambarkan kemampuan modal perusahaan dalam menjamin hutang yang dimiliki dan menunjukkan proporsi pembelanjaan perusahaan yang dibiayai oleh pemegang saham dan dibiayai dari pinjaman, semakin besar hutang yang ditanggung oleh perusahaan, maka secara tidak langsung risiko yang ditanggung pemilik oleh modal juga akan semakin besar. Hal ini mengakibatkan perusahaan akan kesulitan mencari pihak yang ingin berinvestasi atau pihak yang ingin meminjamkan dananya kepada perusahaan. Oleh karena itu, kondisi tersebut menimbulkan keinginan manajemen untuk melakukan praktik perataan laba (Santoso, 2010). Financial leverage yang menunjukkan seberapa efisien perusahaan memanfaatkan ekuitas pemilik dalam dalam rangka mengantisipasi hutang jangka pendek dan jangka panjang perusahaan, sehingga tidak akan mengganggu operasi perusahaan secara keseluruhan dalam jangka panjang (Pratamasari, 2006). Hutang yang besar mengakibatkan risiko semakin meningkat. Jadi, semakin besar leverage, maka risiko yang ditanggung oleh pemilik modal juga akan semakin meningkat. 
Financial leverage yang besar menyebabkan turunnya minat investor untuk menanamkan modalnya pada perusahaan tersebut, sehingga dapat memicu adanya perataan laba.

\section{LANDASAN TEORI DAN HIPOTESIS}

\section{Cash Holding}

Pada dasarnya, setiap perusahaan memegang sejumlah uang tunai. Hal ini dikarenakan uang tunai memiliki peran penting dalam memenuhi kebutuhan simpanan jangka pendek atau mempunyai peran pada bagian yang lebih besar, seperti portofolio jangka panjang. Berdasarkan The General Theory of Employment, Interset \& Money, Keynes menjelaskan bahwa terdapat tiga variabel atau motif kepemilikan kas, yaitu:

1. Motif Transaksi

Dalam hal ini, kas digunakan untuk membayar barang dan jasa atau transaksi sehari-hari.

2. Motif berjaga-jaga

Dalam hal ini, kas digunakan untuk investasi (misalnya berupa saham atau obligasi) investasi dianggap aman karena jarang kehilangan nilai (tidak mengalami inflasi).

3. Motif Spekulasi

Dalam hal ini, para investor mengharapkan tingkat pengembalian yang sebesarbesarnya dari investasi yang dilakukan.

Menurut Opler et al (dalam telebenia dan Darvish, 2012) ada tiga teori tentang variabel mengapa perusahaan memegang kas pada level yang tinggi. Tiga teori tersebut adalah:

\section{Trade-off theory}

Trade-off theory menyatakan bahwa perusahaan menentukan jumlah kas perusahaan yang dioptimalkan melalui penyeimbangan biaya marjinal dan manfaat marjinal dari kas yang dipegang. Menurut Sarwinda (2015), hal yang penting dari trade-off theory adalah bahwa dengan adanya tingkat kas yang diinginkan perusahaan, maka manajemen melalui pendekatan aktif dapat membuat keputusan terhadap kepemilikan kas berdasarkan pada analisis biaya manfaat. Dalam rangka memaksimalkan kekayaan pemegang saham, manajemen harus mengelola kas perusahaan induk sedemikian rupa sehinga manfaat akhir dari kas akan disamakan dengan biaya akhir.

2. Teori Hirarki Pembiayaan (financing hierarchy theory)

Pendekatan teori hirarki pembiayaan tentang kepemilikan kas berasal dari teori struktur modal yang dikemukakan oleh Myers dan Majluf(1984), Dalam hal pembiayaan, teori hirarki menyatakan bahwa perusahaan pertama kali memulai investasi dengan dividen kumulatif. Kemudian mereka mulai dengan kewajiban yang aman, setelah itu dengan kewajiban yang berisiko dan akhirnya dengan pembiayaan. Ketika arus kas operasional cukup untuk pembiayaan investasi baru, perusahaan akan membayar hutang dan mengumpulkan uang tunai. Ketika dividen kumulatif tidak cukup untuk pembiayaan investasi saat ini, perusahaan 
menggunakan kepemilikan kas kumulatif dan jika diperlukan perusahaan akan membuat hutang Cendy (2013).

3. Teori Arus Kas Bebas (free cash flow theory)

Menurut teori arus kas bebas (free cash flow theory), dalam rangka meningkatkan sumber daya yang berada dibawah kendali mereka, manajemen cenderung menambah kas untuk memanfaatkan kekuasaan dalam mengambil keputusan dan diskriminasi dalam mengambil keputusan perusahaan, karena perusahaan melakukan investasi dengan kas perusahaan maka, tidak perlu memberikan informasi rinci kepada pasar modal. Namun, manajemen dapat membuat investasi memiliki efek pada kekayaan pemegang saham (Cendy, 2013).

\section{Profitabilitas}

Rasio Profitabilitas adalah rasio yang digunakan untuk menilai kemampuan perusahaan dalam mencari keuntungan (Kasmir:2008:196). Rasio ini mengukur tingkat efektivitas manajemen suatu perusahaan. Hal ini ditunjukan oleh laba yang dihasilkan dari penjualan dan pendapatan investasi.

\section{Financial Leverage}

Financial leverage merupakan rasio yang digunakan untuk mengukur sejauh mana aktiva perusahaan dibiayai dengan hutang. Wiagustini (2010:76) menyebutkan financial leverage adalah kemampuan perusahaan untuk memenuhi kewajiban finansialnya baik dalam jangka pendek maupun jangka pajang atau mengukur sejauh mana perusahaan dibiayai oleh hutangnya.

Rasio ini mempunyai beberapa implikasi yaitu para pemberi kredit akan melihat kepada modal untuk melihat batasan keamanan pemberi kredit, yang ke dua, dengan menggunakan hutang pemberi dampak yang positif bagi pemilik karena perusahaan memperoleh dana tetapi pemilik tidak kehilangan kendali atas perusahaan, dan apabila perusahaan mendapatkan keuntungan yang lebih besar dari beban bunga, maka keuntungan bagi pemilik modal sendiri akan menjadi lebih besar (Bernadetha, 2010).

\section{Income Smoothing}

Menurut Harahap (2007: 245) perataan laba adalah usaha yang dilaksanakan oleh menajemen untuk menstabilkan laba. Perataan laba adalah "meratakan earnings yang dilaporkan atas pengurangan secara sengaja fluktuasi di sekitar tingkat earning tertentu yang dianggap normal bagi suatu perusahaan”. Perataan laba adalah pengurangan fluktuasi laba dari tahun ke tahun dengan memindahkan pendapatan dari tahun-tahun yang tinggi pendapatannya ke periode-periode yang kurang menguntungkan.

Fuddenberg dan Tirole dalam Haryadi (2011), berpendapat bahwa perataan laba adalah suatu proses manipulasi waktu terjadinya laba atau laporan laba agar laba yang dilaporkan terlihat stabil. Income smoothing yang dilaporkan dapat didefinisikan sebagai usaha yang disengaja untuk diratakan atau memfluktuasikan tingkat laba sehingga pada saat sekarang dipandang normal bagi suatu perusahaan. Dalam hal ini income smoothing menunjukan suatu usaha manajemen perusahaan untuk mengurangi variasi abnormal laba dalam batas-batas yang diijinkan dalam praktik akuntansi dan prinsip manajemen yang wajar, Ghozali dan Chairiri (2007). 


\section{METODE PENELITIAN}

\subsection{Teknik Pengumpulan Data}

Jenis penelitian yang digunakan adalah dengan metode pendekatan kuantitatif (Sugiyono, 2017:77). Jenis data yang digunakan dalam penelitian ini adalah data sekunder berupa laporan keuangan tahunan yang dipublikasikan oleh masing-masing perusahaan manufaktur sektor industri dasar dan kimia yang terdaftar di BEI serta melalui website www.idx.co.id.

\subsection{Operasional Variabel}

Operasional dari masing-masing variabel penelitian sebagai berikut:

a. Variabel Dependen

Variabel dependen dalam penelitian ini adalah income smoothing (perataan laba) skala pengukuran ini adalah nominal atau dummy, variabel dependen dalam penelitian ini adalah berukuran kategori atau dikotomi Ghozali (2013:337).

Konsep dasar dari regresi logistik variabelnya adalah harus dinyatakan sebagai variabel dummy dengan memberikan kode 1 atau 0 . Oleh karena itu penelitian ini dibagi dua kelompok yaitu kelompok perusahaan yang melakukan tindakan perataan laba diberi nilai 1 (satu) sedangkan kelompok perusahaan yang tidak melakukan perataan laba diberi nilai 0 (nol). Income smoothing (perataan laba) diuji dengan indeks eckel (1981) dalam Lusi (2017) menggunakan Coefficient Variation (CV) variabel penghasilan dan variabel penjualan bersih, yang dapat dirumuskan sebagai berikut:

Indeks Eckel $=\frac{\mathrm{CV} \Delta \mathrm{I}}{\mathrm{CV} \Delta \mathrm{S}}$

Keterangan:

$\Delta \mathrm{I} \quad=$ Perubahan laba (income) dalam satu periode

$\Delta \mathrm{S} \quad=$ Perubahan penjualan (sales) dalam satu periode

$\mathrm{CV} \quad=$ Koefisien variasi dari variabel yaitu standar deviasi dibagi dengan nilai yang diharapkan

$\mathrm{CV} \Delta \mathrm{I} \quad=$ Koefisien variasi untuk perubahan laba (income)

$\mathrm{CV} \Delta \mathrm{S}=$ Koefisien variasi untuk perubahan penjualan (sales)

Nilai $\mathrm{CV} \Delta \mathrm{S}$ dan $\mathrm{CV} \Delta \mathrm{I}$ dihitung dengan rumus:

$\mathrm{CV} \Delta \mathrm{S}$ atau $\mathrm{CV} \Delta \mathrm{I}=\sqrt{\frac{\sum(\Delta \mathrm{x}-\overline{\Delta \mathrm{x}})^{2}}{n-1}}: \overline{\Delta \mathrm{x}}$

Keterangan:

$\Delta \mathrm{x}=$ Perubahan laba (I)/penjualan (S) antara tahun $\mathrm{n}$ dengan tahun $\mathrm{n}-1$

$\overline{\Delta \mathrm{x}}=$ Rata-rata perubahan laba (I)/penjualan (S) antara tahun $\mathrm{n}$ dengan tahun $\mathrm{n}-1$

$\mathrm{n} \quad$ = Banyaknya tahun yang diamati

Karena income smoothing merupakan variabel dummy, maka disimbol dengan:

- Jika nilai Indeks Eckel $\geq 1$, maka perusahaan tidak melakukan perataan laba dan diberi simbol 0.

- Jika nilai Indeks Eckel $<1$, maka perusahaan melakukan praktik perataan laba dan diberi simbol 1. 
b. Variabel Independen

1. Cash holding

Cash holding diukur dengan menggunakan cash to asset ratio yaitu dengan menjumlah kas dan setara kas dibagi total aset/aktiva, atau dapat dirumuskan sebagai berikut:

Cash Holding $=\frac{\text { kas }+ \text { setara kas }}{\text { total aktiva }}$

2. Profitabilitas

Profitabilitas diukur dengan menggunakan rasio net profit margin, menurut Kasmir (2015:19) pengukuran net profit margin dapat dirumuskan sebagai berikut:

Net Profit Margin $=\frac{\text { laba bersih setelah pajak }}{\text { penjualan bersih }} \times 100 \%$

\section{Financial Leverage}

Financial leverage diproksikan dengan rasio debt to equity ratio, dengan rumus sebagai berikut:

$\mathrm{DER}=\frac{\text { total hutang }}{\text { total modal }}$

\subsection{Teknik Pengumpulan Sampel}

Populasi dalam penelitian ini adalah seluruh perusahaan manufaktur sektor industri dasar dan kimia yang terdaftar di BEI periode 2013-2017, data tersebut diperoleh dengan mengakses laporan keuangan di situs www.idx.co.id dan memperoleh populasi berjumlah 66 (enam puluh enam) perusahaan.

Pemilihan sampel penelitian ini menggunakan teknik purposive sampling, yaitu dipilih atas dasar kesesuaian karakteristik sampel yang ditentukan. Karakteristik sampel yang diambil sebagai berikut:

1. Perusahaan manufaktur sektor industri dasar dan kimia yang terdaftar di Bursa Efek Indonesia periode 2013-2017.

2. Perusahaan manufaktur sektor industri dasar dan kimia yang pada periode 2013-2017 laporan keuangan tidak merugi.

3. Perusahaan manufaktur sektor industri dan kimia yang pada periode 2013-2017 laporan keuangan tidak menggunakan mata uang rupiah.

4. Perusahaan manufaktur sektor industri dasar dan kimia yang pada periode 2013-2017 tidak mengalami delisting.

Maka dengan karakteristik tersebut, diperoleh sampel perusahaan manufaktur sektor industri dasar dan kimia sebanyak 22 perusahaan dengan periode amatan 5 tahun, maka diperoleh observasi sebanyak 110 dan data yang diteliti berupa proxy dari variabel yang di dapat dari website masing-masing perusahaan laporan posisi keuangan, laporan laba rugi, laporan perubahan ekuitas selama periode 20132017.

\subsection{Teknik Analisis Data}

Teknik analisis data menggunakan statistik deskriptif dan analisis regresi logistik (logistik regression). Uji regresi logistik dilakukan karena variabel dependen dalam penelitian ini dalah variabel dummy/ nominal. Tujuan dilakukan 
regresi logistik adalah pembuatan sebuah model regresi untuk memprediksi besar variabel dependen yang merupakan sebuah variabel binary menggunakan data variabel independen yang sudah diketahui besarnya Ghozali (2013: 335).

Statistik deskriptif digunakan untuk menggambarkan variabel-variabel dalam penelitian. Menurut Ghozali (2013: 19) stastistik deskriptif diperlukan untuk melihat gambaran keseluruhan dari sampel yang berhasil dikumpulkan dan memenuhi syarat untuk dijadikan sampel peneliti.

Regresi logistik (logistic regression) hanya variabel dependennya yang merupakan variabel dummy (1 dan 0). Disamping itu, teknik analisis ini tidak memerlukan normalitas, uji heteroskedasitas, dan uji asumsi klasik pada variabel bebasnya (Ghozali, 2013: 337).

Untuk menguji apakah faktor-faktor yang dapat mempengaruhi income smoothing digunakan Eviews versi 7.0 dan Microsoft Excel untuk mengelola data penelitian. Secara sistematis model penelitian yang digunakan sebagai berikut:

Persamaan logistic regression dalam penelitian ini adalah:

$\operatorname{Ln}\left(\frac{p}{1-p}\right)=\beta 0+\beta 1 \mathrm{CH}+\beta 2 \mathrm{NPM}+\beta 3$ DER

Apabila hubungan antara odds dan probabilitas adalah:

$\frac{\mathrm{p}}{1-\mathrm{p}}$

Keterangan:

$\operatorname{Ln}\left(\frac{\mathrm{p}}{1-\mathrm{p}}\right)$ : Odds ratio atau rasio probabilitas

$\mathrm{P} \quad$ : Profitabilitas perusahaan yang melakukan income smoothing

1-P : Probabilitas perusahaan yang tidak melakukan income smoothing

B0 : Konstanta

$\quad \beta 1 \mathrm{CH} \quad$ : Koefisien regresi logistik untuk variabel cash holding

$\beta 2 \mathrm{NPM} \quad$ : Koefisien regresi logistik untuk variabel net profit margin

$\beta 3$ DER : Koefisien regresi logistik variabel debt to equity ratio

Interprestasi hasil koefisien regresi logistik tidak langsung menggunakan koefisien secara langsung pada yang tertera dari hasil pengolahan Eviews, namun menggunakan odds ratio dengan rumus adalah $2,72^{\mathrm{e}}$, huruf e pangkat dimaksud disini yaitu koefisien yang tertera pada hasil pengolahan persamaan regresi logistik (Ghozali:2013: 351).

Menurut Ghozali (2013: 343), goodness of fit test dapat dilakukan dengan melihat hasil dari hosmer and lemeshow dengan hipotesis sebagai berikut:

1. Ho : Model yang dihipotesiskan fit dengan data

2. Ha : Model yang dihipotesiskan tidak fit dengan data

Jika nilai uji statistik hosmer and lemeshow sama dengan atau kurang dari 0,05, maka hipotesis nol (Ho) ditolak dan hal tersebut berarti terdapat perbedaan signifikan antara model dengan nilai observasinya sehingga goodness of fit test model tidak baik karena model tidak dapat mempredikasi nilai observasinya. Sebaliknya jika nilai uji statistik hosmer and lemeshow lebih dari 0,05 maka hipotesis (Ho) tidak dapat ditolak, yang berarti model mampu memprediksi nilai observasi atau dapat dikatakan model dapat diterima karena cocok dengan observasinya. 
Koefisien tidak di evaluasi menggunakan statistik t, tetapi menggunakan statistik $\mathrm{Z}$ dan dapat dilakukan dengan membandingkan nilai probabilitas terhadap $\alpha$, jika nilai $<\alpha$, maka Ho ditolak yang berarti bahwa variabel independen mempengaruhi variabel dependen, sedangakan jika nilai $>\alpha$, maka Ho diterima yang berarti bahwa variabel independen tidak mempengaruhi variabel dependen. Uji likelihood ratio (LR test) sama halnya dengan uji F untuk menganalisis secara simultan pengaruh variabel-variabel independen terhadap variabel dependen, uji likelihood ratio dapat dilakukan dengan membandingkan nilai chi-square tabel, jika nilai chi-square hitung > nilai chi-square tabel.

Uji koefisien determinasi (McFadden R-squared), model summary dalam regresi logistik sama dengan pengujian koefisien determinasi $\mathrm{R}^{2}$ pada persamaan regresi liniear. Tujuan dari model summary adalah untuk mengetahui seberapa besar kombinasi variabel independen mampu menjelaskan variasi variabel dependen. Pada hasil data menggunakan Eviews dengan metode regresi logistik akan menghasilkan koefisien determinasi McFadden.

\section{ANALISIS DATA DAN DISKUSI HASIL}

\subsection{Analisis Data}

Sebelum melakukan pengujian, maka terlebih dahulu perlu disajikan uji statistik deskriptif untuk memberikan informasi atau memberikan gambaran terhadap objek yang diteliti melalui data sampel atau populasi (Sugiyono, 2017: 29). Analisis ini hanya berupa akumulasi data dasar dalam bentuk deskripsi semata dalam arti tidak mencari atau menerangkan hubungan, menguji hipotesis, atau melakukan penarikan kesimpulan. Berikut adalah hasil deskriptif statistik:

Tabel 1: Hasil Deskriptif Statistik

\begin{tabular}{|l|c|c|c|c|}
\hline & IS & CH & NPM & DER \\
\hline Mean & 0.545455 & 0.139982 & 8.157636 & 0.950445 \\
\hline Median & 1.000000 & 0.068500 & 5.670000 & 0.641500 \\
\hline Maximum & 1.000000 & 0.702000 & 27.03000 & 5.152000 \\
\hline Minimum & 0.000000 & 0.002000 & 0.650000 & 0.040000 \\
\hline Std. Dev. & 0.500208 & 0.161831 & 7.120560 & 0.978294 \\
\hline Skewness & -0.182574 & 1.812936 & 1.186662 & 2.301910 \\
\hline Kurtosis & 1.033333 & 6.099155 & 3.512594 & 9.459543 \\
\hline & & & & \\
\hline Jarque-Bera & 18.33843 & 104.2786 & 27.02067 & 288.3872 \\
\hline Probability & 0.000104 & 0.000000 & 0.000001 & 0.000000 \\
\hline & & & & \\
\hline Sum & 60.00000 & 15.39800 & 897.3400 & 104.5490 \\
\hline Sum Sq. Dev. & 27.27273 & 2.854624 & 5526.559 & 104.3194 \\
\hline & & & & \\
\hline Observations & 110 & 110 & 110 & 110 \\
\hline Subr: Data din & & & & \\
\hline
\end{tabular}

Sumber: Data diolah, 2018

Pada Tabel 1 disajikan mengenai pengujian statistik deskriptif mengenai pengaruh cash holding, profitabilitas yang diproksikan dengan net profit margin 
(NPM), financial leverage yang diproksikan dengan debt to equity ratio (DER) terhadap income smoothing.

Tabel 1 menunjukkan nilai rata-rata (mean) IS (income smoothing) sebesar 0.5454 dengan standar deviasi sebesar 0.5002, nilai minimum sebesar 0.0000 , nilai maksimum sebesar 1.0000, dan variabel $\mathrm{CH}$ (cash holding) menunjukkan nilai rata-rata (mean) sebesar 0.1400 , nilai minimum sebesar 0.0020 , nilai maksimum sebesar 0.7020 dan nilai standar deviasi sebesar 0.1618 , variabel profitabilitas yang diproksikan dengan net profit margin (NPM) menunjukkan nilai rata-rata (mean) sebesar 8.1576, nilai maksimum sebesar 27.0300, nilai minimum sebesar 0.6500 dan standar deviasi sebesar 7.1206, sedangkan variabel financial leverage yang diproksikan dengan debt to equity ratio (DER) menunjukan nilai rata-rata (mean) sebesar 0.9504, nilai maksimum sebesar 5.1520, nilai minimum sebesar 0.0400 dan standar deviasi sebesar 0.9783 .

a. Uji Analisis Regresi Logistik

Menurut Gujarati dan Porter (2012: 173-175) dan Ghozali (2013: 281-282) model regresi regresi logistik (logistic regression/logit model) disebut sebagai model probabilitas. Model probabilitas tidak menggunakan normalitas karena sama seperti variabel independen, galat atau residual hanya memiliki dua nilai, yaitu mereka mengikuti distribusi probabilitas Bernoulli (1 jika kejadian terjadi dan 0 jika kejadian tidak terjadi).

Dependent Variable: IS

Tabel 2: Hasil Uji Analisis Regresi Logistik

Method: ML - Binary Logit (Quadratic hill climbing)

Date: $12 / 30 / 18$ Time: $14: 40$

Sample: 1110

Included observations: 110

Convergence achieved after 4 iterations

Covariance matrix computed using second derivatives

\begin{tabular}{lllll}
\hline \hline Variable & Coefficient & Std. Error & z-Statistic & Prob. \\
\hline \hline C & $\mathbf{- 1 . 6 3 2 3 3 4}$ & 0.583219 & -2.798835 & 0.0051 \\
CH & $\mathbf{- 1 . 1 2 9 9 5 9}$ & 1.938749 & -0.582829 & 0.5600 \\
NPM & $\mathbf{0 . 1 4 4 2 6 7}$ & 0.049875 & 2.892575 & 0.0038 \\
DER & $\mathbf{0 . 9 1 4 4 3 1}$ & 0.360852 & 2.534085 & 0.0113 \\
\hline \hline McFadden R-squared & 0.104166 & Mean dependent var & 0.545455 \\
S.D. dependent var & 0.500208 & S.E. of regression & 0.476893 \\
Akaike info criterion & 1.307203 & Sum squared resid & 24.10726 \\
Schwarz criterion & 1.405403 & Log likelihood & -67.89618 \\
Hannan-Quinn criter. & 1.347033 & Deviance & 135.7924 \\
Restr. Deviance & 151.5820 & Restr. log likelihood & -75.79102 \\
LR statistic & 15.78968 & Avg. log likelihood & -0.617238 \\
Prob(LR statistic) & 0.001252 & & 110 \\
\hline \hline Obs with Dep=0 & 50 & \multicolumn{5}{|l}{ Total obs } & \\
Obs with Dep=1 & 60 & & \\
\hline \hline
\end{tabular}

Sumber: Data diolah, 2018 
Berdasarkan Tabel 2 diatas, maka dapat diperoleh persamaan regresi logistik sebagai berikut:

$$
\begin{aligned}
& \mathbf{L n}\left(\frac{\mathbf{p}}{\mathbf{1 - p}}\right)=-1.632334026-1.129959439 * \mathrm{CH}+0.1442673871 * \mathrm{NPM}+ \\
& 0.9144306956 * \mathrm{DER}
\end{aligned}
$$

Dari model persamaan regresi diatas, dapat dijelaskan sebagai berikut:

1. Berdasarkan pesamaan regresi tersebut didapat konstanta sebesar $-1,632334026$ yang berarti jika seluruh variabel independen konstan atau sama dengan nol, maka variabel income smoothing turun sebesar $1.63 \%$.

2. Koefisien variabel cash holding sebesar -1.129959439 dan tidak berpengaruh pada $\alpha=5 \%$. Jika menghitung odd ratio -1.12 , dapatkan hasil sebesar $\mathrm{e}^{-1.12}=$ 0,33. Jika variabel lainnya dianggap konstan maka cash holding kemungkinan income smoothing menurun sebesar 0,33\% untuk setiap kenaikan cash holding dengan nilai odd ratio sebesar $0,33 \%$.

3. Koefisien dari variabel rasio keuangan profitabilias yang diproksikan dengan net profit margin (NPM) sebesar 0.1442673871 dan berpengaruh pada $\alpha=5 \%$. Jika menghitung odd ratio dari 0. 144, dapatkan hasil sebesar $\mathrm{e}^{0.144 .}=1.15$. Hal ini berarti jika net profit margin (NPM) meningkat 1\%, maka kemungkinan meningkatnya income smoothing sebesar $1.15 \%$ dengan asumsi variabel lainnya konstan.

4. Koefisen dari variabel rasio keuangan financial leverage yang diproksikan dengan debt to equity (DER) sebesar 0.9144306956 dan berpengaruh signifikan pada $\alpha=5 \%$, jika menghitung odd ratio dari 0.914 , didapatkan hasil sebesar $\mathrm{e}^{0.914}=2.49$. Hal ini berarti jika persentase debt to equity ratio (DER) meningkat 1\%, maka kemungkinan meningkatnya income smoothing sebesar $2.49 \%$ dengan asumsi variabel lainnya konstan.

b. Uji Goodness of fit (Hosmer \& Lemeshow)

Tabel 3: Uji Goodness of Fit Test (Hosmer \& Lemeshow)

Goodness-of-Fit Evaluation for Binary Specification

Andrews and Hosmer-Lemeshow

Tests

Equation: EQ01

Date: 01/08/19 Time: 12:36

\begin{tabular}{|c|c|c|c|c|c|c|c|c|}
\hline & \multicolumn{2}{|c|}{ Quantile of Risk } & \multirow[b]{2}{*}{ Actual } & \multirow{2}{*}{$\begin{array}{l}\text { Dep=0 } \\
\text { Expect }\end{array}$} & \multirow[b]{2}{*}{ Actual } & \multirow{2}{*}{$\begin{array}{l}\text { Dep=1 } \\
\text { Expect }\end{array}$} & \multirow{2}{*}{$\begin{array}{l}\text { Total } \\
\text { Obs }\end{array}$} & \multirow{2}{*}{$\begin{array}{l}\text { H-L } \\
\text { Value }\end{array}$} \\
\hline & Low & High & & & & & & \\
\hline 1 & 0.1627 & 0.2992 & 8 & 8.16045 & 3 & 2.83955 & 11 & 0.01222 \\
\hline 2 & 0.3089 & 0.4261 & 6 & 7.00590 & 5 & 3.99410 & 11 & 0.39776 \\
\hline 3 & 0.4270 & 0.4616 & 5 & 6.07537 & 6 & 4.92463 & 11 & 0.42517 \\
\hline 4 & 0.4629 & 0.4865 & 5 & 5.78417 & 6 & 5.21583 & 11 & 0.22421 \\
\hline 5 & 0.4952 & 0.5152 & 3 & 5.45524 & 8 & 5.54476 & 11 & 2.19223 \\
\hline 6 & 0.5160 & 0.5553 & 7 & 5.16731 & 4 & 5.83269 & 11 & 1.22585 \\
\hline 7 & 0.5586 & 0.5874 & 7 & 4.71591 & 4 & 6.28409 & 11 & 1.93647 \\
\hline 8 & 0.5980 & 0.6953 & 7 & 3.92004 & 4 & 7.07996 & 11 & 3.75977 \\
\hline 9 & 0.6956 & 0.8241 & 2 & 2.57666 & 9 & 8.42334 & 11 & 0.16853 \\
\hline 10 & 0.8442 & 0.9677 & 0 & 1.13894 & 11 & 9.86106 & 11 & 1.27048 \\
\hline
\end{tabular}

Grouping based upon predicted risk (randomize ties) 


\begin{tabular}{|c|c|c|c|c|c|}
\hline Total & 50 & 50.0000 & 60.0000 & 110 & 11.6127 \\
\hline H-L Statistic & 11.6127 & & Prob. Chi-Sq(8) & 0.1693 & \\
\hline Andrews Statistic & 22.4737 & & Prob. Chi-Sq(10) & 0.0129 & \\
\hline
\end{tabular}

Sumber: Data diolah, 2018

Hasil pengolahan data menunjukkan bahwa hasil HL Statistik 11.6127 dengan probabilitas chi-square $0.1693>\alpha(0,05)$ yang berarti nilainya melebihi 0,05 yang mana dapat diartikan bahwa Ho ditolak dan Ha diterima (model dapat diterima).

c. Uji statistik Z

Tabel 4: Uji Statistik Z

\begin{tabular}{lrrrr} 
Variable Coefficient & Std. Error & z-Statistic & \multicolumn{2}{l}{ Prob. } \\
\hline \hline C & -1.632334 & 0.583219 & -2.798835 & 0.0051 \\
CH & -1.129959 & 1.938749 & -0.582829 & $\mathbf{0 . 5 6 0 0}$ \\
NPM & 0.144267 & 0.049875 & 2.892575 & $\mathbf{0 . 0 0 3 8}$ \\
DER & 0.914431 & 0.360852 & 2.534085 & $\mathbf{0 . 0 1 1 3}$ \\
\hline
\end{tabular}

Sumber: Data diolah, 2018

Berdasarkan Tabel 4, maka hasil uji statistik Z dari masing-masing variabel independen terhadap variabel dependen sebagai berikut:

1. Variabel cash holding

Hasil pengolahan data menunjukkan cash holding memiliki nilai probabilitas sebesar 0,5600 , apabila dibandingkan antara $\alpha=5 \%$, maka nilai probabilitas cash holding $0,5600>$ nilai $\alpha(0,05)$, sehingga dapat disimpulkan menolak Ha dan menerima Ho yang berarti variabel cash holding tidak berpengaruh secara signifikan terhadap income smoothing.

2. Variabel profitabilitas

Hasil pengolahan data variabel profitabilitas yang diproksikan dengan net profit margin (NPM) memiliki nilai sebesar 0,0038 , apabila dibandingkan antara $\alpha=5 \%$ maka nilai probabilitas $0,0038<$ nilai $\alpha(0,05)$, sehingga dapat disimpulkan menerima Ha dan menolak Ho yang berarti variabel profitabilitas yang diproksikan dengan net profit margin berpengaruh positif dan signifikan terhadap income smoothing.

\section{Variabel Financial Leverage}

Hasil pengolahan data variabel financial leverage yang diproksikan dengan debt to equity ratio (DER) memiliki nilai sebesar 0,0113 , apabila dibandingkan antara $\alpha=5 \%$, maka nilai probabilitas $0,0113<$ nilai $\alpha(0,05)$, sehingga dari nilai output tersebut dapat disimpulkan bahwa menerima Ha dan menolak Ho yang berarti variabel financial leverage yang diproksikan dengan debt to equity ratio (DER) berpengaruh positif dan signifikan terhadap income smoothing.

d. Uji Likelihood Ratio (LR Test)

Uji statistik likelihood ratio (LR Test) pada regresi logistik sebagai berikut:

McFadden R-squared

S.D. dependent var

Akaike info criterion

Schwarz criterion

Hannan-Quinn criter.

Restr. Deviance

\section{Tabel 5: Uji Likelihood Ratio}

$\begin{array}{lll}0.104166 & \text { Mean dependent var } & 0.545455 \\ 0.500208 & \text { S.E. of regression } & 0.476893 \\ 1.307203 & \text { Sum squared resid } & 24.10726 \\ 1.405403 & \text { Log likelihood } & -67.89618 \\ 1.347033 & \text { Deviance } & 135.7924 \\ 151.5820 & \text { Restr. log likelihood } & -75.79102\end{array}$




\begin{tabular}{llll} 
LR statistic & 15.78968 & Avg. log likelihood & -0.617238 \\
Prob(LR statistic) & $\mathbf{0 . 0 0 1 2 5 2}$ & & \\
Obs with Dep $=0$ & 50 & Total obs & 110 \\
Obs with Dep $=1$ & 60 & & \\
\hline \hline
\end{tabular}

Sumber: Data diolah, 2018

Berdasarkan hasil estimasi dapat diperoleh nilai LR statistik atau chi-square hitung adalah 15.78968, sedangkan nilai chi-square tabel df $4, \alpha=0,05$ adalah sebesar 9,48773. Maka dapat disimpulkan bahwa LR statistik atau chi-square $>$ nilai chi-square tabel dan dapat juga dilihat Uji LR dengan membandingkan Prob (LR statistics) pada $\alpha$, nilai Prob (LR statistic) $0.001252<0.05$, maka keputusan adalah menolak Ho dan menerima Ha yang berarti semua variabel independen diantaranya cash holding, profitabilitas, dan financial leverage secara bersamasama mempengaruhi variabel dependen yaitu income smoothing.

e. Uji Koefisien Determinasi (McFadden R-Squared)

Pada perhitungan regresi logistik, tidak menggunakan nilai koefisien $\mathrm{R}^{2}$ konvensional untuk mengukur kebaikan garis regresi. Sebagai penggantinya, digunakan koefisien determinasi yang dikembangkan oleh McFadden, hasil output Eviews sebagai berikut:

\begin{tabular}{|c|c|c|c|}
\hline \multicolumn{4}{|c|}{ Tabel 6: Uji Koefisiensi Determinasi (McFadden R-Squared) } \\
\hline McFadden R-squared & 0.104166 & Mean dependent var & 0.545455 \\
\hline S.D. dependent var & 0.500208 & S.E. of regression & 0.476893 \\
\hline Akaike info criterion & 1.307203 & Sum squared resid & 24.10726 \\
\hline Schwarz criterion & 1.405403 & Log likelihood & -67.89618 \\
\hline Hannan-Quinn criter. & 1.347033 & Deviance & 135.7924 \\
\hline Restr. Deviance & 151.5820 & Restr. log likelihood & -75.79102 \\
\hline LR statistic & 15.78968 & Avg. log likelihood & -0.617238 \\
\hline Prob(LR statistic) & 0.001252 & & \\
\hline Obs with Dep $=0$ & 50 & Total obs & 110 \\
\hline Obs with Dep=1 & 60 & & \\
\hline
\end{tabular}

Sumber: Data diolah, 2018

Pada Tabel 6, didapatkan informasi bahwa nilai Mcfadden R-squared yaitu 0,104166 yang berarti bahwa variabel independen yaitu cash holding, profitabilitas, financial leverage (DER) memiliki nilai 10,41\% untuk perubahan probabilitas terhadap variabel dependen yaitu income smoothing dan 89,59\% dijelaskan oleh variabel independen lain diluar model penelitian.

\subsection{Diskusi}

Pada tahap ini disajikan uraian mengenai hasil uji statistik sebagai berikut:

a. Cash holding terhadap income smoothing

Berdasarkan hasil penelitian, dapat dilihat bahwa nilai probabilitas variabel independen cash holding sebesar 0.5600 bila dibandingkan dengan $\alpha=5 \%$ maka nilai probabilitas $(0.5600)>\alpha(0.05)$ sehingga dapat diambil keputusan untuk menolak Ha dan menerima Ho. Hal ini dapat disimpulkan bahwa variabel rasio keuangan cash holding tidak berpengaruh terhadap income smoothing.

Cash holding tidak berpengaruh pada income smoothing, hal ini berarti tinggi rendahnya cash holding perusahaan tidak berpengaruh pada income smoothing, kemungkinan terjadi karena terdapat perusahaan yang tidak memiliki 
cash holding yang cukup untuk melakukan income smoothing, (Algery, 2012). Disamping itu perusahaan di Indonesia memiliki sedikit aliran kas bebas, ketika perusahaan tidak cukup untuk membiayai dividen atau mendanai investasi pada proyek baru perusahaan maka tindakan perusahaan selanjutnya yaitu mengakumulasi kas (cash holding) atau bahkan melakukan pendanaan melalui hutang. Hasil penelitian ini sejalan dengan hasil penelitian Tampubolon (2012) dan Algery (2012) yang menyatakan cash holding tidak memiliki pengaruh yang terhadap income smoothing yang dilakukan perusahaan.

b. Profitabilitas terhadap income smoothing

Hasil pengolahan data variabel profitabilitas yang diproksikan dengan net profit margin (NPM) memiliki nilai sebesar 0,0038 , apabila dibandingkan antara $\alpha=5 \%$ maka nilai probabilitas $0,0038<$ nilai $\alpha(0,05)$, sehingga dapat disimpulkan menerima Ha dan menolak Ho yang berarti variabel profitabilitas berpengaruh positif dan signifikan terhadap income smoothing.

Hal ini dijelaskan bahwa semakin kecil profitabilitas yang diproksikan dengan net profit margin (NPM) maka kemungkinan perusahaan melakukan perataan laba semakin tinggi maka perusahaan akan mempunyai nilai tambah bagi calon investor pontensial, dimana diharapkan akan tertarik membeli saham perusahaan. Hasil penelitian ini sejalan dengan penelitian yang dilakukan oleh Dewi (2012).

\section{c. Financial leverage terhadap income smoothing}

Berdasarkan uji $\mathrm{Z}$ diketahui bahwa variabel financial leverage yang diproksikan dengan debt to equity ratio (DER) berpengaruh positif dan signifikan terhadap income smoothing (perataan laba). Nilai probabilitas yang positif sebesar 0.0113 pada $\alpha(0,05)$.

Debt to equity ratio (DER) merupakan bagian dari dari financial leverage yaitu sebuah rasio untuk mengukur seberapa baik struktur permodalan perusahaan. Debt to equity ratio menggambarkan kemampuan modal sendiri pada perusahaan dalam menjamin seluruh hutang yang dimiliki dan menunjukkan proporsi pembelanjaan perusahaan yang dibiayai oleh pemegang saham dan dibiayai dari pinjaman. Semakin besar hutang yang ditanggung oleh perusahaan, maka secara tidak langsung risiko yang ditanggung pemilik modal juga akan semakin besar. Hal ini mengakibatkan perusahaan yang ingin meminjamkan dananya kepada perusahaan. Oleh karena itu, kondisi tersebut menimbulkan keinginan manajemen sebuah perusahaan melakukan praktik perataan laba. Hasil penelitian ini sejalan dengan penelitian yang dilakukan oleh Rahmawati (2012),

d. Cash holding, profitabilitas dan financial leverage terhadap income smoothing

Hasil penelitian ini menunjukkan nilai Prob (LR statistic) $0.001252<0.05$, maka keputusannya adalah menolak Ho dan menerima Ha yang berarti semua variabel independen (cash holding, profitabilitas, dan financial leverage) secara bersama-sama (simultan) mempengaruhi variabel dependen (income smoothing). 


\section{KESIMPULAN}

Berdasarkan hasil analisis regresi logistik dari pengaruh rasio keuangan yaitu cash holding, profitabilitas yang diproksikan dengan net profit margin (NPM) dan financial leverage yang diproksikan dengan debt to equity ratio (DER) terhadap income smoothing pada manufaktur sektor industri dasar dan kimia periode 2013-2017 dapat diambil kesimpulan sebagai berikut:

1. Cash holding tidak berpengaruh terhadap income smoothing.

2. Profitabilitas yang diproksikan dengan net profit margin (NPM) berpengaruh terhadap income smoothing.

3. Financial leverage yang diproksikan dengan debt to equity ratio (DER) berpengaruh terhadap income smoothing.

4. Cash holding, profitabilitas yang diproksikan dengan net profit margin (NPM), financial leverage yang diproksikan dengan debt equity ratio (DER) berpengaruh secara simultan income smoothing.

Keterbatasan dari penelitian ini antara lain:

1. Penelitian ini hanya menguji variabel cash holding, profitabilitas yang diproksikan dengan net profit margin (NPM), dan financial leverage yang diproksikan dengan debt to equity ratio (DER) terhadap income smoothing, sedangkan banyak sekali variabel rasio keuangan dan faktor lain yang dapat dijadikan kajian terhadap income smoothing.

2. Masih kurangnya penggunaan sampel data dalam penelitian ini, yaitu menggunakan data laporan keuangan pada perusahaan manufaktur sektor industri dasar dan kimia yang terdaftar di BEI.

Saran dalam penelitian ini diharapkan dapat menyempurnakan penelitian dan pengembangan ilmu pengetahuan dari berbagai pihak, diantaranya:

1. Penelitian selanjutnya diharapkan menambah sampel yang digunakan yakni seluruh perusahaan manufaktur perusahaan sektor industri dasar dan kimia yang terdaftar di BEI.

2. Penelitian selanjutnya diharapkan menambah atau menggunakan variabelvariabel lain yang diduga dapat memberikan model pendugaan income smoothing yang lebih baik.

3. Penelitian selanjutnya diharapkan menggunakan rentang waktu yang lebih lama agar hasil income smoothing lebih digambarkan secara akurat dan baik.

\section{DAFTAR PUSTAKA}

Algery, A. (2013). Pengaruh Profitabilitas, Financial Leverage, dan Harga Saham Terhadap Praktek Perataan Laba Pada Perusahaan Manufaktur yang Terdaftar di Bursa Efek Indonesia. Jurnal Akuntansi, Vol.1, No.3, 1-11.

Belkaoui, A. R. (2006). Accounting Theory: Teori Akuntansi Buku 1-5/E. Jakarta: Salemba Empat.

Budiasih, I. (2009). Faktor-faktor yang Mempengaruhi Praktik Perataan Laba. Jurnal Akuntansi dan Bisnis, Vol.4, No.1, 1-14. 
Dina Rahmawati, D. M. (2012). Analisis Faktor-faktor yang Berpengaruh Terhadap Praktik Perataan Laba (Studi Pada Perusahaan Manufaktur yang Terdaftar di BEI Tahun 2007-2010). Diponegoro Journal of Accounting, Vol.1, No.1, 200-213.

Eko Budi Santoso, S. N. (2012). Pengaruh Profitabilitas, Financial Leverage, Dividen, Ukuran Perusahaan, Kepemilikan Institusional, dan Kelompok Usaha Terhadap Perataan Laba Studi Kasus Pada Perusahaan NonFinansial yang Terdaftar di BEI. Conference in Business, Accounting, and Management (CBAM), Vol.1, No.1, 185-200.

Harahap, S. S. (2018). Teori Akuntansi. Jakarta: RajaGrafindo Persada.

Harris Prasetya, S. N. (2013). Pengaruh Ukuran Perusahaan, Profitabilitas, Financial Leverage, Klasifikasi KAP dan Likuiditas Terhadap Praktik Perataan Laba. Diponegoro Journal of Accounting, Vol.2, No.4, 188-194.

Hery. (2016). Analisis Laporan Keuangan-Integrated and Comprehensive Edition. Jakarta: Gramedia Widiasarana Indonesia.

I Made Arya Dwiputra, I. K. (2016). Pengaruh Return On Assets, Net Profit Margin, Debt to Equity Ratio, Size pada Perataan Laba. E-Jurnal Akuntansi, Vol.16, No.1, 129-155.

Imam Ghozali, D. R. (2013). Analisis Multivariat dan Ekonometrika: Teori, Konsep, dan Aplikasi dengan EVIEWS 8. Semarang: Badan Penerbit Universitas Diponegoro.

Kartika Shintia Dewi, P. (2012). Analisis Pengaruh ROA, NPM, DER, dan Size Terhadap Praktik Perataan Laba (Studi Kasus Pada Perusahaan Manufaktur yang Terdaftar di Bursa Efek Indonesia Periode 2007-2010). Diponegoro Journal of Management, Vol.1, No.4, 172-180.

Kasmir. (2018). Analisis Laporan Keuangan. Jakarta: RajaGrafindo Persada.

Mamduh M Hanafi, A. H. (2009). Analisis Laporan Keuangan. Yogyakarta: UPP STIM YKPN.

Milka Erika Mambraku, P. B. (2014). Pengaruh Cash Holding dan Struktur Kepemilikan Manajerial Terhadap Income Smoothing (Studi Empiris Pada Perusahaan Manufaktur yang Terdaftar di Bursa Efek Indonesia Tahun 2010-2012). Diponegoro Journal of Accounting, Vol.3, No.2, 758-766.

Muchammad, A. (2001). Faktor-faktor yang Mempengaruhi Tindakan Perataan Laba/Income Smoothing (Penelitian pada Perusahaan Manufaktur yang Go Public di Bursa Efek Surabaya Periode Tahun 1993-1996). Fakultas Ekonomi dan Bisnis-Universitas Airlangga.

Pratamasari, F. (2006). Analisis Faktor-faktor yang Mempengaruhi Praktik Perataan Laba (Income Smoothing) Pada Perusahaan Manufaktur dan Keuangan yang Terdaftar di BEJ. e-Jurnal Fakultas Ekonomi Universitas Brawijaya Malang.

Ramadhona, S. (2017). Analisis Faktor-faktor yang Mempengaruhi Praktik Perataan Laba (Income Smoothing) (Studi Empiris Pada Perusahaan yang Terdaftar di Jakarta Islamic Index (JII) Periode 2010-2016). Jakarta: Fakultas Ekonomi dan Bisnis Universitas Islam Negeri Syarif Hidayatullah. 
Robert N. Anthony, V. G. (2005). Management Control System. Jakarta: Salemba Empat.

Scott, W. R. (2006). Financial Accounting Theory 4th Edition. Canada: Toronto Pearson Education, Inc.

Sindi Retno Noviana, E. N. (2011). Analisis Faktor-faktor yang Mempengaruhi Praktik Perataan Laba (Studi Empiris Perusahaan Manufaktur yang Terdaftar di BEI Periode 2006-2010). Jurnal Akuntansi dan Auditing, Vol.8, No.1, 69-82.

Sugiyono. (2017). Statistika Untuk Penelitian. Bandung: Alfabeta.

Sumtaky, O. M. (2007). Faktor-faktor yang Mempengaruhi Praktik Perataan Laba Pada Perusahaan Manufaktur yang Terdaftar di Bursa Efek Jakarta. Malang: Fakultas Ekonomi Universitas Brawijaya.

Tampubolon, M. (2012). Pengaruh Financial Leverage, Free Cash Fow, dan Good Corporate Governance Terhadap Praktik Perataan Laba (Studi Kasus Pada Perusahaan Manufaktur Industri Dasar dan Kimia di Bursa Efek Indonesia). Universitas Gunadarma.

Widyaningdyah, A. (2001). Analisis Faktor-faktor yang Berpengaruh Terhadap Earning Management Pada Perusahaan Go Public di Indonesia. Jurnal Akuntansi \& Keuangan.

Yasintha Pradyamitha Cendy, F. (2013). Pengaruh Cash Holding, Profitabilitas dan Nilai Perusahaan Terhadap Income Smoothing Pada Perusahaan Manufaktur yang Terdaftar di BEI Tahun 2009-2011. Jurnal Fakultas Ekonomi Universitas Diponegoro.

https://akuntansiterapan.com/2016/07/15/mengetahui-perataa-laba=menggunakanindeks-eckel.

http://www.idx.co.id/

http://www.sahamoke.com/

www.idnfinancials.com 